\title{
Extending the Time: Solvothermal Syntheses, Crystal Structures, and Properties of Two Non-isostructural Thioantimonates with the Composition [Mn(tren)] $\mathrm{Sb}_{2} \mathrm{~S}_{4}$
}

\author{
Michael Schaefer, ${ }^{\dagger}$ Daniel Kurowski, ${ }^{\ddagger}$ Arno Pfitzner, ${ }^{\ddagger}$ Christian Năther ${ }^{\dagger}$ Zomaje Rejai, ${ }^{\dagger}$ Karina Möller, ${ }^{\dagger}$ \\ Nancy Ziegler, ${ }^{\dagger}$ and Wolfgang Bensch ${ }^{\star, \dagger}$ \\ Institut für Anorganische Chemie, Christian-Albrechts-Universität Kiel, Olshausenstrasse 40, \\ D-24098 Kiel, Germany, and Institut für Anorganische Chemie, Universität Regensburg, \\ Universitätsstrasse 31, 93040 Regensburg \\ Received November 15, 2005
}

\begin{abstract}
The two novel compounds, [Mn(tren)] $\mathrm{Sb}_{2} \mathrm{~S}_{4}$ (1 and 2), were obtained by the reaction of elemental $\mathrm{Mn}, \mathrm{Sb}$, and $\mathrm{S}$ in aqueous solutions of tren (tren $=$ tris $\left(2\right.$-aminoethyl)amine, $\mathrm{C}_{6} \mathrm{H}_{18} \mathrm{~N}_{4}$ ) after different reaction times. Compound 1 is formed up to a reaction time of $13 \mathrm{~d}$, and an extension of the reaction time leads to the formation of 2 . Both compounds crystallize in monoclinic space groups $\left(1, P 2_{1} / C ; 2, C 2 / c\right)$. In 1, the two unique $\mathrm{SbS}_{3}$ trigonal pyramids share a common $\mathrm{S}$ atom to form a $\mathrm{Sb}_{2} \mathrm{~S}_{5}$ unit. Two $\mathrm{S}$ atoms of this group have a bond to $\mathrm{Mn}^{2+}$ yielding a $\mathrm{MnSb}_{2} \mathrm{~S}_{3}$ heteroring in the boat conformation. The $\mathrm{Sb}_{2} \mathrm{~S}_{5}$ moieties are joined via common corners into the final undulated ${ }_{\infty}^{1}\left[\mathrm{Sb}_{2} \mathrm{~S}_{4}\right]^{2-}$ anion which is directed along [001]. The structure of 2 contains the $[\mathrm{Mn}(\operatorname{tren})]^{2+}$ ion, one $\mathrm{SbS}_{3}$ pyramid, and a $\mathrm{SbS}_{4}$ unit. Two symmetry-related $\mathrm{SbS}_{4}$ groups share an edge, forming a $\mathrm{Sb}_{2} \mathrm{~S}_{6}$ group containing a $\mathrm{Sb}_{2} \mathrm{~S}_{2}$ ring. This group is joined via corners to two $\mathrm{SbS}_{3}$ pyramids on both sides producing a $\mathrm{Sb}_{4} \mathrm{~S}_{4}$ ring. The $\mathrm{Sb}_{2} \mathrm{~S}_{2}$ and $\mathrm{Sb}_{4} \mathrm{~S}_{4}$ rings are condensed into the final ${ }_{\infty}^{1}\left[\mathrm{Sb}_{2} \mathrm{~S}_{4}\right]^{2-}$ anion which runs along [010]. The [Mn(tren)] groups are bound to the thioantimonate(III) backbone on opposite sides of the $\mathrm{Sb}_{4} \mathrm{~S}_{4}$ ring, and a small MnSbS 2 ring is formed. In both structures, weak $S \cdots H$ bonds are found which may contribute to the stability of the materials. The two compounds decompose in one step upon heating, and only $\mathrm{MnS}$ and $\mathrm{Sb}_{2} \mathrm{~S}_{3}$ could be identified as the crystalline part of the decomposition products. Both compounds can also be prepared under solvothermal conditions using $\mathrm{MnSb}_{2} \mathrm{~S}_{4}$ as starting material. Compounds $\mathbf{1}$ and $\mathbf{2}$ are obtained from this ternary material in a high yield.
\end{abstract}

\section{Introduction}

During the past few years we demonstrated that $\mathrm{Mn}^{2+}$ is a very good candidate to be incorporated into thioantimonate(III) anionic frameworks: examples are the series of compounds with composition $\mathrm{Mn}_{2} \mathrm{Sb}_{2} \mathrm{~S}_{5} \cdot \mathrm{L}$ (L = amine). ${ }^{1-3}$ In these compounds $\mathrm{Mn}, \mathrm{Sb}$, and $\mathrm{S}$ atoms form heterocubanes which are joined into a neutral layered structure. One of the two independent $\mathrm{Mn}$ atoms is surrounded in a severely distorted octahedral environment of $6 \mathrm{~S}$ atoms, and the other

* To whom correspondence should be addressed. Fax: +49-(0)431-8801520. E-mail: wbensch@ac.uni-kiel.de.

Christian-Albrechts-Universität Kiel.

$\doteqdot$ Universität Regensburg.

(1) Bensch, W.; Schur, M. Eur. J. Solid State Inorg. Chem. 1996, 33, 1149.

(2) Schur, M.; Näther, C.; Bensch, W. Z. Naturforsch. 2001, 56b, 79.

(3) Engelke, L.; Stähler, R.; Schur, M.; Näther, C.; Bensch, W.; Pöttgen, R.; Möller, M. H. Z. Naturforsch. 2004, 59b, 869.

3726 Inorganic Chemistry, Vol. 45, No. 9, 2006
Mn atom bonds two $2 \mathrm{~N}$ and $4 \mathrm{~S}$ atoms. The amines point into the empty space between successive layers, and the interlayer interactions are weak and of the van der Waals type. A spectacular compound with composition [Mn$\left.\left(\mathrm{C}_{6} \mathrm{H}_{18} \mathrm{~N}_{4}\right)\right]_{4} \mathrm{Mn}_{2} \mathrm{Sb}_{4} \mathrm{~S}_{12}$ contains the formerly unknown heterometallic $\left[\mathrm{Mn}_{2} \mathrm{Sb}_{4} \mathrm{~S}_{12}\right]$ core which is constructed by $\mathrm{MnS}_{4}$ tetrahedra and $\mathrm{SbS}_{3}$ pyramids being linked via common corners and edges. ${ }^{4}$ The $\left[\mathrm{Mn}\left(\mathrm{C}_{6} \mathrm{H}_{18} \mathrm{~N}_{4}\right)\right]^{2+}$ cations are located at the periphery of the core and are bound to the $\left[\mathrm{Mn}_{2} \mathrm{Sb}_{4} \mathrm{~S}_{12}\right]$ unit via two $\mathrm{S}$ atoms. Interesting examples are the two new neutral thioantimonates(III) $[\mathrm{Mn}(\operatorname{tren})]_{2} \mathrm{Sb}_{2} \mathrm{~S}_{5}$ (tren $=$ tris(2-aminoethyl)amine, $\mathrm{C}_{6} \mathrm{H}_{18} \mathrm{~N}_{4}$ ) and [ $\mathrm{Mn}(\text { tren) }]_{2} \mathrm{Mn}_{2} \mathrm{Sb}_{4} \mathrm{~S}_{10}{ }^{5}$ In the former compound trigonal $\mathrm{SbS}_{3}$ pyramids are connected via common corners to give the tetradentate $\left[\mathrm{Sb}_{2} \mathrm{~S}_{5}\right]^{4-}$

(4) Schaefer, M.; Näther, C.; Bensch, W. Solid State Sci. 2003, 5, 1135

(5) Schaefer, M.; Näther, C.; Lehnert, N.; Bensch, W. Inorg. Chem. 2004, $43,2914$.

10.1021/ic0519739 CCC: $\$ 33.50$

(C) 2006 American Chemical Society Published on Web 04/06/2006 
anion of which four $\mathrm{S}$ atoms have bonds to the manganese atoms of the $[\mathrm{Mn}(\operatorname{tren})]^{2+}$ ions. A remarkable feature is the comparably large angle of $134^{\circ}$ around the $\mathrm{S}$ atom joining the two $\mathrm{Sb}$ atoms. In the structure of the second compound, $\mathrm{MnS}_{4}$ tetrahedra and $\mathrm{SbS}_{3}$ pyramids are linked via common corners and edges to form a new heterometallic $\left[\mathrm{Mn}_{2} \mathrm{Sb}_{4} \mathrm{~S}_{10}\right]$ core. The $[\mathrm{Mn}(\operatorname{tren})]^{2+}$ cations are located at the periphery and are bound to the central core via two $\mathrm{S}$ atoms. Finally, the new compounds [TM(tren)] $\mathrm{Sb}_{4} \mathrm{~S}_{7}$ were prepared with TM $=\mathrm{Mn}^{2+}, \mathrm{Fe}^{2+}, \mathrm{Co}^{2+}$, and $\mathrm{Zn}^{2+}{ }^{6}$ In these isostructural compounds, the $\left[\mathrm{Sb}_{4} \mathrm{~S}_{7}\right]^{2-}$ anions are composed of three $\mathrm{SbS}_{3}$ trigonal pyramids and one $\mathrm{SbS}_{4}$ unit which share edges and corners to form semicubes $\left(\mathrm{Sb}_{3} \mathrm{~S}_{4}\right)$. The $\mathrm{Sb}_{3} \mathrm{~S}_{4}$ moieties and $\mathrm{SbS}_{3}$ pyramids are joined in an alternating fashion, yielding the ${ }_{\infty}^{1}\left[\mathrm{Sb}_{4} \mathrm{~S}_{7}{ }^{2-}\right]$ anionic chain. Weaker $\mathrm{Sb}-\mathrm{S}$ bonding interactions between neighbored chains lead to the formation of layers within the (001) plane. The layers contain pockets that are occupied by the cations. The $\mathrm{TM}^{2+}$ ions are in a trigonal bipyramidal environment of four $\mathrm{N}$ atoms of the tren ligand and one $\mathrm{S}$ atom of the thioantimonate(III) anion.

Most syntheses are performed using the elements or binary compounds as staring materials. Very recently we demonstrated that the reaction of the ternary compound $\mathrm{MnSb}_{2} \mathrm{~S}_{4}{ }^{7}$ with dien (dien $=$ diethylenetriamine) yielded the new thioantimonate(III) $\left[\mathrm{Mn}(\text { dien })_{2}\right] \mathrm{Sb}_{4} \mathrm{~S}_{7} \cdot 0.5 \mathrm{H}_{2} \mathrm{O}$ which was not accessible by using the elements as educts. ${ }^{8}$ [Mn(dien $)_{2}$ ]$\mathrm{Sb}_{4} \mathrm{~S}_{7} \cdot 0.5 \mathrm{H}_{2} \mathrm{O}$ was obtained phase pure in high yields which encouraged us to perform more syntheses with $\mathrm{MnSb}_{2} \mathrm{~S}_{4}$ as starting material. Here, we report on the synthesis, crystal structures, and properties of the two novel thioantimonate(III) compounds with the composition $\left[\mathrm{Mn}(\right.$ tren) $] \mathrm{Sb}_{2} \mathrm{~S}_{4}$.

\section{Experimental Section}

Synthesis. The title compounds were synthesized under solvothermal conditions from elemental manganese (54.9 mg, $1 \mathrm{mmol}$ ), antimony (243.5 mg, $2 \mathrm{mmol}$ ), and sulfur (128.3 $\mathrm{mg}, 4 \mathrm{mmol})$ in $5 \mathrm{~mL}$ of a tren $/ \mathrm{H}_{2} \mathrm{O}$ solution $(50 \%)$. The mixtures were heated at $140{ }^{\circ} \mathrm{C}$ for 7 days (1) and 33 days (2) in Teflon-lined steel autoclaves with an inner volume of approximately $30 \mathrm{~mL}$. The products consisting of dark orange (1) and red-orange (2) colored crystals with a polyhedral shape were filtered off, washed with distilled water, and dried in air. The yield was about $80 \%$ for $\mathbf{1}$ and $40 \%$ for 2 .

Both compounds were also obtained using $\mathrm{MnSb}_{2} \mathrm{~S}_{4}(200 \mathrm{mg}$, $0.468 \mathrm{mmol}^{7}$ in $5 \mathrm{~mL}$ of an $90 \%$ aqueous solution of tris $(2-$ aminoethyl)amine (yield of $65-70 \%$ ). The only byproduct of the procedure presented above was elemental antimony which was detected in the X-ray powder patterns.

Long time experiments from 7 to $33 \mathrm{~d}$ were performed using the first synthetic procedure to determine the time when compound $\mathbf{1}$ disappears and compound $\mathbf{2}$ is formed.

CHNS analysis: calcd. C 12.58, H 3.17, N 9.78, S 22.39; found (2) C 12.30, H 2.97, N 9.63, S 22.36; found (1) C 12.35, H 3.05, N 9.69, S 22.03.

(6) Schaefer, M.; Stähler, R.; Kiebach, W.-R.; Näther, C.; Bensch, W. Z. Anorg. Allg. Chem. 2004, 630, 1816.

(7) Pfitzner, A.; Kurowski, D. Z. Kristallogr. 2000, 215, 373.

(8) Schaefer, M.; Kurowski, D.; Pfitzner, A.; Näther, C.; Bensch, W. Acta Crystallogr. 2004, E60, m183.
Structure Determination. The intensity data were collected with an Imaging Plate diffraction system (Fa. Stoe). The raw intensities were treated in the usual way and were corrected for absorption effects using X-Red ${ }^{9}$ and X-Shape. ${ }^{10}$ The structures were solved with direct methods using SHELXS-97, ${ }^{11}$ and structure refinement was performed against $F^{2}$ using SHELXL-97.12 All non-hydrogen atoms except some of the disordered carbon atoms were refined anisotropically. The hydrogen atoms were positioned with idealized geometry and were refined isotropically using a riding model. Three carbon atoms of the ligand in compound $\mathbf{1}$ are disordered and were refined using a split model with anisotropic displacement factors for the major occupied atoms ( $\mathrm{sof}=0.8$ ) and isotropic displacement factors for the minor occupied atoms ( of $=0.2$ ). In 2 , some carbon atoms of the ligand are disordered and were refined anisotropically using a split model ( $s$ of $=0.65$ : 0.35 ). Crystal data, results of the structure refinement, and bond lengths and angles are found in Tables 1 and 2.

Crystallographic data (excluding structure factors) for the structures reported in this paper have been deposited with the Cambridge Crystallographic Data Centre as supplementary publications CCDC185044 (2) and CCDC 600580 (1). Copies of the data can be obtained free of charge on application to CCDC, 12 Union Road, Cambridge CB21EZ, UK (fax (+44)1223-336-033; e-mail: deposit@ccdc.cam.ac.uk).

X-ray Powder Diffractometry. The X-ray powder patterns were recorded on a Stoe Stadi-P diffractometer $(\mathrm{Cu} \mathrm{K} \alpha 1$ radiation, $\lambda=$ $1.540598 \AA$ ) in transmission geometry.

Thermoanalytical Measurements. Thermal investigations were performed on a Netzsch STA-409CD DTA-TG measurement device. All measurements were corrected for buoyancy and current effects. They were performed using a heating rate of $4 \mathrm{~K} / \mathrm{min}$ in $\mathrm{Al}_{2} \mathrm{O}_{3}$ crucibles under a dynamic nitrogen atmosphere (flow rate $75 \mathrm{~mL} / \mathrm{min}$; purity $99.999 \%$; sample weight 11.9 (1) and $15.1 \mathrm{mg}$ (2)).

\section{Results and Discussion}

Crystal Structures. In the two new compounds, [Mn(tren) $] \mathrm{Sb}_{2} \mathrm{~S}_{4}$ ( $\mathbf{1}$ and $\mathbf{2}$ ), all atoms are in general positions. The $\mathrm{Mn}^{2+}$ ions are located in a distorted octahedral environment of four $\mathrm{N}$ atoms of the tren ligand and two $\mathrm{S}$ atoms of the ${ }_{\infty}^{1}\left[\mathrm{Sb}_{2} \mathrm{~S}_{4}\right]^{2-}$ anions (Figures 1 and 2). The $\mathrm{Mn}-\mathrm{N}$ bonds range from $2.240(3)$ to $2.375(3) \AA$ in $\mathbf{1}$ and from $2.235(3)$ to 2.350(3) $\AA$ in 2. The $\mathrm{Mn}-\mathrm{S}$ bond lengths are 2.5181(9) and 2.7494(10) $\AA$ in 1 and 2.4774(10) and 2.7947(9) $\AA$ in 2 (Table 2). As expected the longer $\mathrm{Mn}-\mathrm{N}$ distances are on the opposite side of the short $\mathrm{Mn}-\mathrm{S}$ bond (Table 2). ${ }^{4,5,14,15}$

In $\mathbf{1}$, two $\mathrm{SbS}_{3}$ trigonal pyramids share a common $\mathrm{S}$ atom to form a $\mathrm{Sb}_{2} \mathrm{~S}_{5}$ unit. Two $\mathrm{S}$ atoms of this group have a bond to $\mathrm{Mn}^{2+}$ yielding a $\mathrm{MnSb}_{2} \mathrm{~S}_{3}$ heteroring in the boat conformation (Figures 1 and 2). The $\mathrm{Sb}_{2} \mathrm{~S}_{5}$ moieties are joined via common corners into the final undulated ${ }_{\infty}^{1}\left[\mathrm{Sb}_{2} \mathrm{~S}_{4}\right]^{2-}$ anion (Figure 2) which is directed along [001]. Otherwise, the

(9) X-Red32, version 1.11; Stoe \& Cie GmbH: Darmstadt, Germany, 1998

(10) X-Shape, version 1.03; Stoe \& Cie GmbH: Darmstadt, Germany, 1998.

(11) Sheldrick, G. M. SHELXS-97; University Göttingen: Göttingen, Germany, 1997.

(12) Sheldrick, G. M. SHELXL-97; University Göttingen: Göttingen, Germany, 1997.

(13) Hagen, K. S.; Amstrong, W. H.; Hope, H. Inorg. Chem. 1988, 27, 969.

(14) Ellermeier, J.; Bensch, W. Trans. Met. Chem. 2002, 27, 763.

(15) Laskowski, E. J.; Hendricksen, D. N. Inorg. Chem. 1978, 17, 457. 
Schaefer et al.

Table 1. Selected Data of Data Collection and Refinement Results for Compounds 1 and $\mathbf{2}$

\begin{tabular}{|c|c|}
\hline \multicolumn{2}{|c|}{ compound 1} \\
\hline empirical formula & $\mathrm{C}_{6} \mathrm{H}_{18} \mathrm{MnN}_{4} \mathrm{~S}_{4} \mathrm{Sb}_{2}$ \\
\hline fw & $572.92\left(\mathrm{~g} \mathrm{~mol}^{-1}\right)$ \\
\hline temp & $293(2) \mathrm{K}$ \\
\hline wavelength & $0.71073 \AA$ \\
\hline cryst syst & monoclinic \\
\hline space group & $P 2_{1} / c$ \\
\hline \multirow[t]{3}{*}{ unit cell dimensions } & $\begin{array}{l}a=10.1611(6) \AA \\
b=152439(12) \AA\end{array}$ \\
\hline & $\begin{array}{l}b=15.2439(12) \AA \\
c=11.2964(6) \AA\end{array}$ \\
\hline & $\beta=112.808(6)^{\circ}$ \\
\hline vol & $1612.94(18) \AA^{3}$ \\
\hline$Z$ & 4 \\
\hline density (calcd) & $2.359 \mathrm{Mg} / \mathrm{m}^{3}$ \\
\hline abs coeff & $4.599 \mathrm{~mm}^{-1}$ \\
\hline$F(000)$ & 1092 \\
\hline cryst size & $0.12 \times 0.08 \times 0.06 \mathrm{~mm}^{3}$ \\
\hline$\theta$ range & $2.37-28.14^{\circ}$ \\
\hline \multirow[t]{3}{*}{ index ranges } & $-13 \leq h \leq 13$ \\
\hline & $-20 \leq k \leq 20$ \\
\hline & $-14 \leq l \leq 14$ \\
\hline reflns collected & 17043 \\
\hline independent reflns & $3749[R$ (int $)=0.0283]$ \\
\hline completeness to $\theta=28.14^{\circ}$ & $94.8 \%$ \\
\hline refinement method & full-matrix least-squares on $F^{2}$ \\
\hline data/restraints/params & $3749 / 0 / 167$ \\
\hline $\mathrm{GOF}$ on $F^{2}$ & 1.054 \\
\hline \multirow[t]{2}{*}{ final $\mathrm{R}$ indices $[I>2 \sigma(I)]$} & $\mathrm{R} 1=0.0259$ \\
\hline & $\mathrm{wR} 2=0.0692$ \\
\hline \multirow[t]{2}{*}{$\mathrm{R}$ indices (all data) } & $\mathrm{R} 1=0.0294$ \\
\hline & $\mathrm{wR} 2=0.0711$ \\
\hline extinction coeff & $0.0016(3)$ \\
\hline largest diff. peak and hole & 0.955 and -0.946 e $\AA^{-3}$ \\
\hline \multicolumn{2}{|c|}{ compound 2} \\
\hline empirical formula & $\mathrm{C}_{6} \mathrm{H}_{18} \mathrm{MnN}_{4} \mathrm{~S}_{4} \mathrm{Sb}_{2}$ \\
\hline & 572.92 \\
\hline temp & 293(2) K \\
\hline wavelength & $0.71073 \AA$ \\
\hline cryst syst & monoclinic \\
\hline space group & $C 2 / c$ \\
\hline \multirow[t]{4}{*}{ unit cell dimensions } & $a=23.4380(12) \AA$ \\
\hline & $b=8.8525(7) \AA$ \\
\hline & $c=19.1565(10) \AA$ \\
\hline & $\beta=122.788(5)^{\circ}$ \\
\hline vol & $3341.4(4) \AA^{3}$ \\
\hline$Z$ & 8 \\
\hline density (calcd) & $2.278 \mathrm{Mg} / \mathrm{m}^{3}$ \\
\hline abs coeff & $4.440 \mathrm{~mm}^{-1}$ \\
\hline$F(000)$ & 2184 \\
\hline cryst size & $0.11 \times 0.08 \times 0.06 \mathrm{~mm}^{3}$ \\
\hline$\theta$ range & $2.52-28.05^{\circ}$ \\
\hline \multirow{3}{*}{ index ranges } & $-30 \leq h \leq 28$ \\
\hline & $-11 \leq k \leq 11$ \\
\hline & $-25 \leq l \leq 24$ \\
\hline reflns collected & 15767 \\
\hline \multirow[t]{2}{*}{ independent reflns } & 3895 \\
\hline & {$[R(\mathrm{int})=0.0321]$} \\
\hline completeness to $\theta=28.05^{\circ}$ & $95.9 \%$ \\
\hline refinement method & full-matrix least-squares on $F^{2}$ \\
\hline data/restraints/params & $3895 / 0 / 191$ \\
\hline GOF on $\mathrm{F}^{2}$ & 1.023 \\
\hline \multirow[t]{2}{*}{ final $\mathrm{R}$ indices $[I>2 \sigma(I)]$} & $\mathrm{R} 1=0.0243$ \\
\hline & $\mathrm{wR} 2=0.0591$ \\
\hline \multirow[t]{2}{*}{$\mathrm{R}$ indices (all data) } & $\mathrm{R} 1=0.0304$ \\
\hline & $\mathrm{wR} 2=0.0612$ \\
\hline extinction coeff & $0.00144(7)$ \\
\hline largest diff. peak and hole & 0.851 and -0.705 e $\AA^{-3}$ \\
\hline
\end{tabular}

structure may be described as $\mathrm{MnSb}_{2} \mathrm{~S}_{3}$ rings being interconnected by $\mathrm{S}$ atoms.

The $\mathrm{Sb}-\mathrm{S}$ bond lengths (range of 2.3556(8) $-2.5591(8)$ $\AA$ ) and $\mathrm{S}-\mathrm{Sb}-\mathrm{S}$ angles (range of 87.13(3)-107.66(3) ${ }^{\circ}$ ) are
Table 2: Selected Bond Lengths ( $\AA$ ) and Angles (deg) in Compounds 1 and $2^{a}$

\begin{tabular}{|c|c|c|c|}
\hline \multicolumn{4}{|c|}{ compound $\mathbf{1}^{b}$} \\
\hline $\mathrm{Mn}-\mathrm{N}(2)$ & $2.240(3)$ & $\mathrm{Mn}-\mathrm{N}(3)$ & $2.279(3)$ \\
\hline $\mathrm{Mn}-\mathrm{N}(4)$ & $2.256(3)$ & $\mathrm{Mn}-\mathrm{N}(1)$ & $2.375(3)$ \\
\hline $\mathrm{Mn}-\mathrm{S}(1)$ & $2.5181(9)$ & $\mathrm{Mn}-\mathrm{S}(4)$ & $2.7494(10)$ \\
\hline $\mathrm{Sb}(1)-\mathrm{S}(1)$ & $2.3737(7)$ & $\mathrm{Sb}(2)-\mathrm{S}(4)$ & $2.3556(8)$ \\
\hline $\mathrm{Sb}(1)-\mathrm{S}(2)$ & $2.4282(7)$ & $\mathrm{Sb}(2)-\mathrm{S}(3)$ & $2.4699(7)$ \\
\hline $\mathrm{Sb}(1)-\mathrm{S}(3)$ & $2.4693(8)$ & $\mathrm{Sb}(2)-\mathrm{S}(2 \mathrm{~A})$ & $2.5591(8)$ \\
\hline $\mathrm{S}(2)-\mathrm{Sb}(2 \mathrm{~B})$ & $2.5591(8)$ & & \\
\hline $\mathrm{N}(2)-\mathrm{Mn}-\mathrm{N}(4)$ & $144.20(11)$ & $N(4)-M n-S(1)$ & $90.90(8)$ \\
\hline $\mathrm{N}(2)-\mathrm{Mn}-\mathrm{N}(3)$ & $90.48(12)$ & $\mathrm{N}(3)-\mathrm{Mn}$ & $93.31(9)$ \\
\hline $\mathrm{N}(4)-\mathrm{Mn}-\mathrm{N}(3)$ & $98.88(12)$ & $\mathrm{N}(1)-\mathrm{Mn}$ & $159.62(7)$ \\
\hline $\mathrm{N}(2)-\mathrm{Mn}-\mathrm{N}(1)$ & $74.37(10)$ & $\mathrm{N}(2)-\mathrm{Mn}-\mathrm{S}(4)$ & $81.60(9)$ \\
\hline $\mathrm{N}(4)-\mathrm{Mn}-\mathrm{N}(1)$ & $74.89(10)$ & $\mathrm{N}(4)-\mathrm{Mn}-\mathrm{S}(4)$ & $87.12(8)$ \\
\hline $\mathrm{N}(3)-\mathrm{Mn}-\mathrm{N}(1)$ & $75.00(11)$ & $\mathrm{N}(3)-\mathrm{Mn}-\mathrm{S}(4)$ & $172.02(9)$ \\
\hline $\mathrm{N}(2)-\mathrm{Mn}-$ & $123.17(8)$ & $\mathrm{N}(1$ & \\
\hline $\mathrm{S}(1)-\mathrm{Sb}(1)-$ & 107.66 & $\mathrm{~S}(1)$ & 91.8 \\
\hline$S(1)-S b(1)-S(3)$ & $95.26(3)$ & $S(4)-S b(2)-S(3)$ & $102.68(3)$ \\
\hline $\mathrm{S}(2)-\mathrm{Sb}(1)-\mathrm{S}(3)$ & $90.24(3)$ & $S(4)-S b(2)-S(2 A)$ & $96.89(3)$ \\
\hline & & $S(3)-S b(2)-S(2 A)$ & $87.13(3)$ \\
\hline \multicolumn{4}{|c|}{ compound $\mathbf{2}^{c}$} \\
\hline $\mathrm{Mn}-\mathrm{N}(3$ & $235(3)$ & $\mathrm{Mn}-\mathrm{N}$ & 2.2 \\
\hline $\mathrm{Mn}-\mathrm{N}(2)$ & $2.267(3)$ & $\mathrm{Mn}-\mathrm{N}(1)$ & $2.350(3)$ \\
\hline $\mathrm{Mn}-\mathrm{S}(1)$ & $2.7947(9)$ & $\mathrm{Mn}-\mathrm{S}(2)$ & $2.4774(10)$ \\
\hline $\mathrm{Sb}(1)-\mathrm{S}(1)$ & $2.4048(8)$ & $\mathrm{Sb}(2)-\mathrm{S}(4 \mathrm{~A})$ & $2.4018(12)$ \\
\hline $\mathrm{Sb}(1)-\mathrm{S}(2)$ & $2.4312(8)$ & $\mathrm{Sb}$ & $2.4234(8)$ \\
\hline $\mathrm{Sb}(1)-\mathrm{S}(3)$ & $2.5046(8)$ & $\mathrm{Sb}(2)-\mathrm{S}(4)$ & $2.6143(9)$ \\
\hline $\mathrm{S}(3)-\mathrm{Sb}(2 \mathrm{~B})$ & $2.4234(8)$ & $\mathrm{Sb}(2)-\mathrm{S}(1)$ & $2.8564(8)$ \\
\hline $\mathrm{S}(4)-\mathrm{Sb}(2 \mathrm{~A})$ & $2.4018(12)$ & & \\
\hline $\mathrm{N}(3)$ & J & $N$ & $101.41(9)$ \\
\hline $\mathrm{N}(3$ & ) & $\mathrm{N}($ & 174.41(9) \\
\hline $\mathrm{N}(2)-\mathrm{Mn}-\mathrm{N}(4)$ & $143.71(12)$ & $\mathrm{N}(3)-\mathrm{Mn}-\mathrm{S}(1)$ & $173.48(9)$ \\
\hline $\mathrm{N}(3)-\mathrm{Mn}-\mathrm{N}(1)$ & 76.91(11) & $\mathrm{N}(2)-\mathrm{Mn}-\mathrm{S}(1)$ & $81.24(7)$ \\
\hline $\mathrm{N}(2)-\mathrm{Mn}-\mathrm{N}(1)$ & $75.87(12)$ & $\mathrm{N}(4)-\mathrm{Mn}-\mathrm{S}(1)$ & $82.31(8)$ \\
\hline $\mathrm{N}(4)-\mathrm{Mn}-\mathrm{N}(1)$ & $74.78(12)$ & $\mathrm{N}(1)-\mathrm{Mn}-\mathrm{S}(1)$ & $98.23(8)$ \\
\hline $\mathrm{N}(3)-\mathrm{Mn}-\mathrm{S}(2)$ & $100.02(9)$ & $\mathrm{S}(2)-\mathrm{Mn}-\mathrm{S}(1)$ & $85.17(3)$ \\
\hline $\mathrm{N}(2)-\mathrm{Mn}-\mathrm{S}(2)$ & $109.14(9)$ & $\mathrm{S}(4)-\mathrm{Sb}(2)-\mathrm{S}(1)$ & $175.83(3)$ \\
\hline $\mathrm{S}(1)-\mathrm{Sb}(1)-\mathrm{S}(2)$ & $95.34(3)$ & $\mathrm{Sb}(1)-\mathrm{S}(1)-\mathrm{Mn}$ & $84.65(2)$ \\
\hline $\mathrm{S}(1)-\mathrm{Sb}(1)-\mathrm{S}(3)$ & $100.41(3)$ & $\mathrm{Sb}(1)-\mathrm{S}(1)-\mathrm{Sb}(2)$ & $102.33(3)$ \\
\hline $\mathrm{S}(2)-\mathrm{Sb}(1)-\mathrm{S}(3)$ & $90.02(3)$ & $\mathrm{Mn}-\mathrm{S}(1)-\mathrm{Sb}(2)$ & $121.16(3)$ \\
\hline$S(4 A)-S b(2)-S(3 B)$ & $100.86(4)$ & $\mathrm{Sb}(1)-\mathrm{S}(2)-\mathrm{Mn}$ & $91.39(3)$ \\
\hline$S(4 A)-S b(2)-S(4)$ & $88.08(3)$ & $\mathrm{Sb}(2 \mathrm{~B})-\mathrm{S}(3)-\mathrm{Sb}(1)$ & $106.78(3)$ \\
\hline $\mathrm{S}(3 \mathrm{~B})-\mathrm{Sb}(2)-\mathrm{S}(4)$ & $88.92(3)$ & $\mathrm{Sb}(2 \mathrm{~A})-\mathrm{S}(4)-\mathrm{Sb}(2)$ & $91.92(3)$ \\
\hline$b(2)-S(1)$ & $87.86(3)$ & & \\
\hline $\mathrm{S}(3 \mathrm{~B})-\mathrm{Sb}(2)-\mathrm{S}(1)$ & $90.90(2)$ & & \\
\hline
\end{tabular}

${ }^{a}$ Estimated standard deviations are given in parentheses. ${ }^{b}$ Symmetry transformation codes: A $x,-y+1 / 2, z-1 / 2 ; \mathrm{B} x,-y+1 / 2, z+1 / 2$. ${ }^{c}$ Symmetry transformation codes: $\mathrm{A}-x+1,-y+2,-z ; \mathrm{B}-x+1,-y$ $+1,-z$.

typical for thioantimonate(III) compounds (Table 2). ${ }^{1-6,16-23}$ The analysis of the packing and orientation of neighboring chains yields some interesting results. Along [010], the $[\mathrm{Mn}(\mathrm{tren})]^{2+}$ ions of neighboring chains show an antiparallel orientation; along [100], they are oriented in the same direction (Figure 3), and along [001], they are packed so that the organic parts are always oriented face-to-face (Figure 3 bottom).

The $\mathrm{Sb}$ atoms each have one long contact to a $\mathrm{S}$ atom in the chain $(\mathrm{Sb}(2)-\mathrm{S}(1)=3.113(3) \AA, \quad \mathrm{Sb}(1)-\mathrm{S}(3)=$

(16) Powell, A. V.; Boisière, S.; Chippindale, A. M. Chem. Mater. 2000, $12,182$.

(17) Graf, H. A.; Schäfer, H. Z. Naturforsch. 1972, 27b, 735.

(18) Stephan, H.-O.; Kanatzidis, M. G. J. Am. Chem. Soc. 1996, 118, 12226.

(19) Wang, X.; Liebau, F. Acta Crystallogr. 1996, B52, 7.

(20) Schaefer, M.; Näther, C.; Bensch, W. Chem. Mon. 2004, 135, 461.

(21) Stähler, R.; Bensch, W. J. Chem. Soc., Dalton Trans. 2001, 2518.

(22) Stähler, R.; Näther, C.; Bensch, W. Eur. J. Inorg. Chem. 2001, 1835.

(23) Volk, K.; Schäfer, H. Z. Naturforsch. 1979, 34b, 1637. 

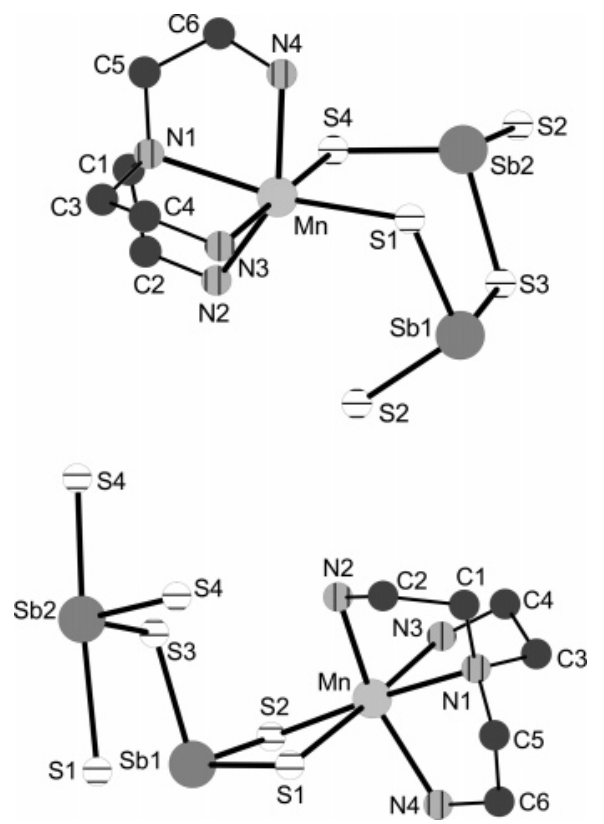

Figure 1. $[\mathrm{Mn}(\mathrm{tren})]^{2+}$ cation and its interconnection with the $\mathrm{SbS}_{3}$ pyramids in 1 (top) and the cation together with the $\mathrm{SbS}_{3} / \mathrm{SbS}_{4}$ groups in 2 (bottom). Note: Disordered $\mathrm{C}$ atoms and $\mathrm{H}$ atoms are omitted for clarity.

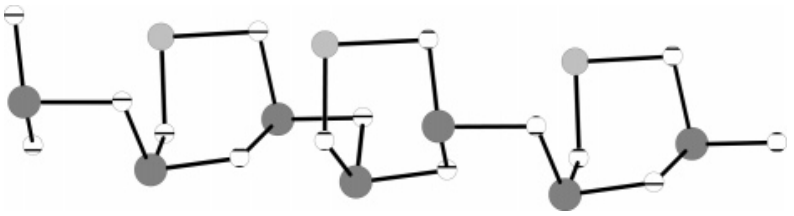

Figure 2. Backbone of $[\mathrm{Mn}(\operatorname{tren})] \mathrm{Sb}_{2} \mathrm{~S}_{4}(\mathbf{1})$. Note: $\mathrm{C}, \mathrm{N}, \mathrm{H}$ atoms are omitted for clarity. The atom coding is identical with that in Figure 1.

3.257(3) ̊̊). Thus, $\psi$-trigonal bipyramidal polyhedra result when the lone electron pair located in the equatorial plane is taken into account. The presence of five intermolecular $\mathrm{H} \cdots \mathrm{S}$ distances ranging from 2.630 to $2.963 \AA$ and $\mathrm{N}-\mathrm{H} \cdots \mathrm{S}$ angles between 133.55 and $178.70^{\circ}$ indicate weak hydrogen bonding.

The ${ }_{\infty}^{1}\left[\mathrm{Sb}_{2} \mathrm{~S}_{4}\right]^{2-}$ anion in 2 is composed of one $\mathrm{Sb}(1) \mathrm{S}_{3}$ trigonal pyramid and a $\mathrm{Sb}(2) \mathrm{S}_{4}$ unit. $\mathrm{Sb}-\mathrm{S}$ bond lengths and $\mathrm{S}-\mathrm{Sb}-\mathrm{S}$ angles for $\mathrm{Sb}(1) \mathrm{S}_{3}$ are in the typical range (Table 2). ${ }^{1-6,16-23} \mathrm{In}$ the $\mathrm{Sb}(2) \mathrm{S}_{4}$ unit, two longer $\mathrm{Sb}-\mathrm{S}$ bonds are observed (2.6143(9) and 2.8564(8) @) (Table 2) which are trans to each other with an angle of $175.83(3)^{\circ}$. Such $\mathrm{SbS}_{4}$ groups are not uncommon and were observed in [ $\mathrm{Zn}(\operatorname{tren})]-$ $\mathrm{Sb}_{4} \mathrm{~S}_{8},{ }^{20}[\mathrm{Co}$ (tren) $] \mathrm{Sb}_{4} \mathrm{~S}_{8},{ }^{21}\left[\mathrm{Fe}(\text { dien })_{2}\right] \mathrm{Sb}_{6} \mathrm{~S}_{10} \cdot 0.75 \mathrm{H}_{2} \mathrm{O},{ }^{22}$ and $\mathrm{Cs}_{2} \mathrm{Sb}_{8} \mathrm{~S}_{13} .{ }^{23}$ The $\mathrm{S}(1)$ and $\mathrm{S}(2)$ atoms are bound to the $\mathrm{Mn}^{2+}$ ion forming a $\mathrm{MnSbS}_{2}$ heteroring. Two symmetry-related $\mathrm{Sb}(2) \mathrm{S}_{4}$ moieties share an edge, forming a $\mathrm{Sb}_{2} \mathrm{~S}_{6}$ group containing a $\mathrm{Sb}_{2} \mathrm{~S}_{2}$ ring. This group is joined via corners to two $\mathrm{Sb}(1) \mathrm{S}_{3}$ pyramids on both sides yielding a $\mathrm{Sb}_{4} \mathrm{~S}_{4}$ ring. The $\mathrm{Sb}_{2} \mathrm{~S}_{2}$ and $\mathrm{Sb}_{4} \mathrm{~S}_{4}$ rings are condensed to the final ${ }_{\infty}^{1}\left[\mathrm{Sb}_{2} \mathrm{~S}_{4}\right]^{2-}$ anion which runs along [010] (Figure 4). The $[\mathrm{Mn}(\mathrm{tren})]$ groups are bound to the thioantimonate(III) backbone on opposite sides of the $\mathrm{Sb}_{4} \mathrm{~S}_{4}$ ring (Figure 4).

$\mathrm{The} \mathrm{Sb}(1)$ atom has two long contacts to $\mathrm{S}$ atoms within the chain $(\mathrm{Sb}(1)-\mathrm{S}(1)=3.225(1) \AA, \quad \mathrm{Sb}(1)-\mathrm{S}(4)=$ 3.281(1) $\AA$ ), and the environment may be regarded as a distorted rectangular pyramid with the lone electron pair most
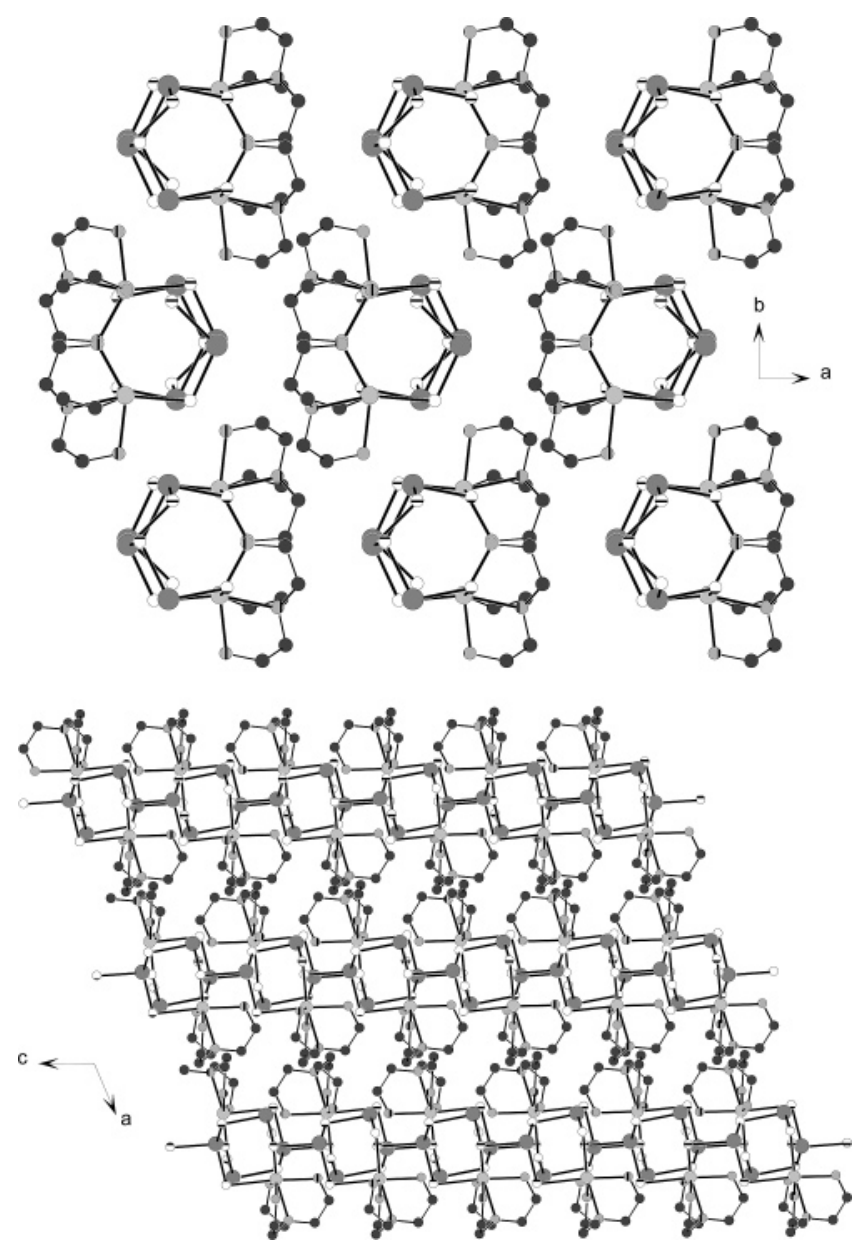

Figure 3. Two different views of the arrangement of the chains in 1: (top) view along [001] and (bottom) view along [010]. Note: $\mathrm{H}$ atoms are not shown, and the atom coding is that used in Figure 1.

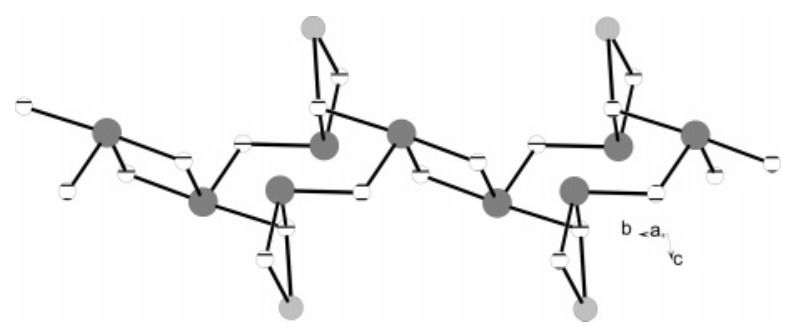

Figure 4. Backbone of the chain in compound 2. The $\mathrm{C}, \mathrm{N}$, and $\mathrm{H}$ atoms are not displayed. The atom coding is that used in Figure 1.

likely occupying the free apical position (i.e., the coordination polyhedron is a distorted $\psi$-octahedron). In Figure 5, two different views of the packing of the chains are shown. Neighboring chains along [010] are arranged such that the tren ligand points into pockets which are formed by the interconnected $\mathrm{SbS}_{4}$ units (Figure 5, top). In the (010) plane, the chains are arranged in a layerlike fashion (Figure 5, bottom).

Five short $\mathrm{H} \cdots \mathrm{S}$ distances between 2.610 and $2.818 \AA$ with corresponding $\mathrm{N}-\mathrm{H} \cdots \mathrm{S}$ angles ranging from 140.33 to $166.91^{\circ}$ indicate weak hydrogen bonding between adjacent chains.

Thioantimonates with the composition $[\mathrm{M}(\mathrm{amine})] \mathrm{Sb}_{2} \mathrm{~S}_{4}$ are rare, and only two other examples exist. In the twodimensional compound $\left[\mathrm{Co}(\right.$ tren) $] \mathrm{Sb}_{2} \mathrm{~S}_{4}{ }^{24}$ the anion is built 

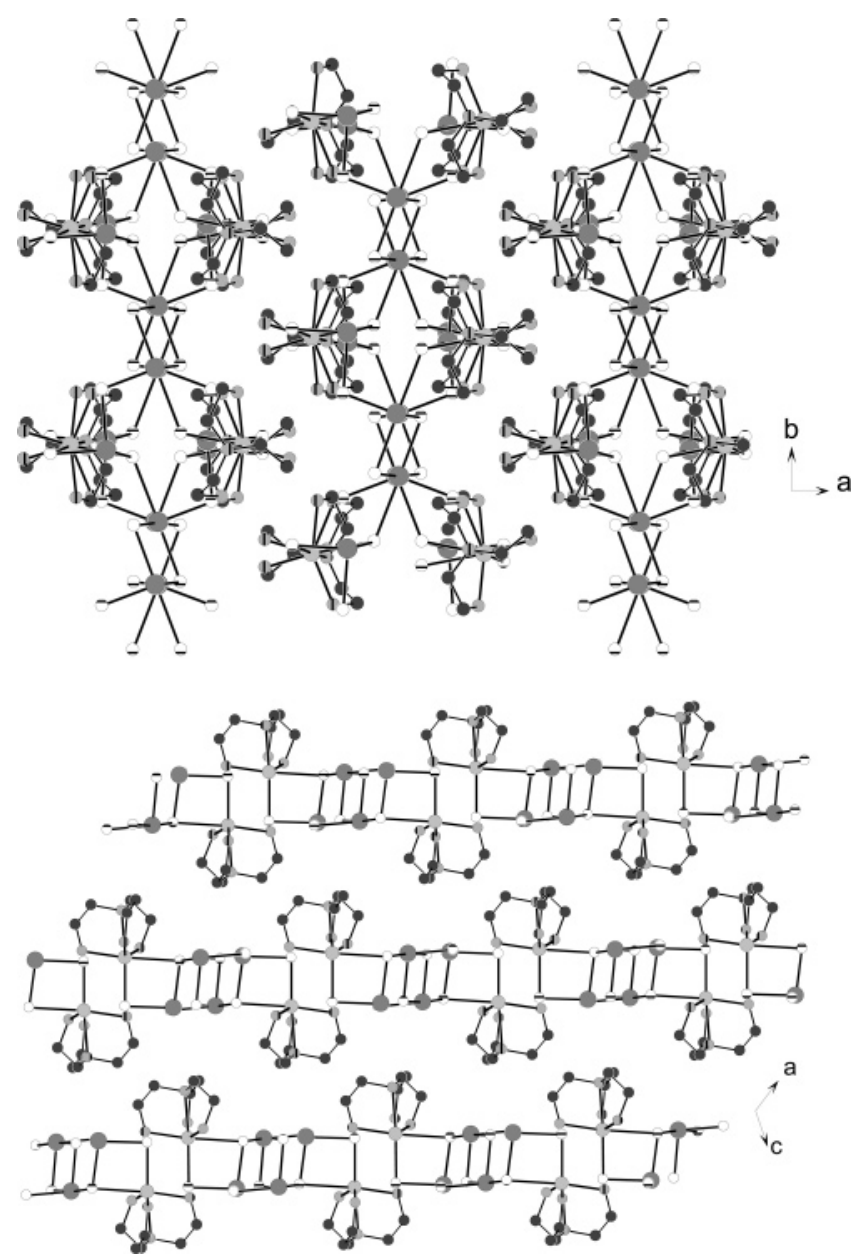

Figure 5. Two different views of the arrangement of the chains in compound 2: (top) view along [001] and (bottom) view along [010].

up from a $\mathrm{SbS}_{3}$ trigonal pyramid and a $\mathrm{SbS}_{4}$ unit. Two of the $\mathrm{SbS}_{4}$ units share a common edge, forming the well-known $\mathrm{Sb}_{2} \mathrm{~S}_{2}$ heterorings. ${ }^{16}$ Four $\mathrm{Sb}_{2} \mathrm{~S}_{2}$ heterorings are joined via four $\mathrm{SbS}_{3}$ units yielding a squarelike net with a large $\mathrm{Sb}_{10} \mathrm{~S}_{10}$ ring. The cavities of the rings are filled by the $[\mathrm{Co}(\text { tren })]^{2+}$ ions. In $\left[\mathrm{Ni}(\right.$ tren) $] \mathrm{Sb}_{2} \mathrm{~S}_{4},{ }^{24}$ the anion is composed of two $\mathrm{SbS}_{3}$ pyramids sharing a common corner to form an onedimensional chain. An interesting feature of this compound is a $\mathrm{NiSb}_{2} \mathrm{~S}_{3}$ ring in the twist conformation. In $\left(\mathrm{CH}_{3} \mathrm{NH}_{3}\right)_{2}-$ $\mathrm{Sb}_{2} \mathrm{~S}_{4}$, two pyramidal $\mathrm{SbS}_{3}$ groups are linked via an edge to give dimeric $\mathrm{Sb}_{2} \mathrm{~S}_{4}{ }^{2-}$ anions, which are then joined via longer $\mathrm{Sb}-\mathrm{S}$ bonds into one-dimensional chains.

Synthetic Aspects. The two new compounds were obtained under identical synthesis conditions but after different reaction times. This observation demonstrates that under solvothermal conditions after short reaction times the less stable material is formed first and the more stable compound crystallizes at later stages of the reaction. According to our long-term experiments, compound $\mathbf{1}$ is formed up to about 13 days, and via the extension of the syntheses beyond this time compound $\mathbf{2}$ is formed. The $\mathrm{X}$-ray powder patterns gave no hints for the coexistence of the two compounds independently of the reaction time. One interesting finding is that compound $\mathbf{1}$ has a higher density than compound $\mathbf{2}$ (Table

(24) Stähler, R.; Bensch, W. Eur. J. Inorg. Chem. 2001, 3073.

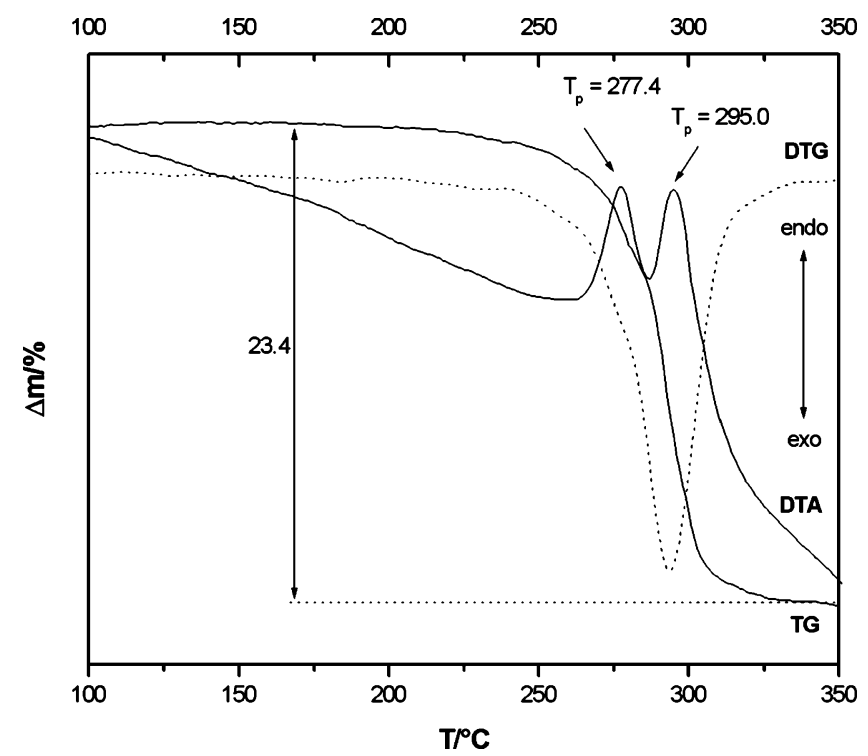

Figure 6. DTA, TG, and DTG curves for compound $1\left(T_{\mathrm{p}}=\right.$ peak temperature).

1). In another experiment, some crystals of $\mathbf{2}$ were added to the reaction mixture. After 7 days only crystals of compound 2 were found in the reaction product. When the syntheses are performed in Teflon liners which were formerly used for the preparation of compound $\mathbf{2}$ only this material crystallized. These observations are hints that compound $\mathbf{2}$ is more stable than $\mathbf{1}$.

Normally, one would expect that the more stable material exhibits the higher density. However, this is just a crude rule and several exceptions are known. The observations for $\mathbf{1}$ and 2 agree well with the unusual behavior of $\mathrm{MnSb}_{2} \mathrm{~S}_{4}$ which exhibits a high-density high-pressure polymorph, $o P 28$, first reported in ref 25 and a lower density roomtemperature polymorph, $m C 28$, which is supposed to be more stable. $^{7}$

Another interesting result was obtained with syntheses which used $\mathrm{MnSb}_{2} \mathrm{~S}_{4}$ as the starting material. The ratio of the elements is identical with that found in the products. But according to the results of X-ray powder diffraction, elemental $\mathrm{Sb}$ was formed as a byproduct clearly indicating that a redox reaction occurred. It is highly likely that this redox reaction took place with the amine. During the reaction with $\mathrm{MnSb}_{2} \mathrm{~S}_{4}$, the primary building units, $\mathrm{SbS}_{3}$ pyramids and $\mathrm{MnS}_{6}$ octahedra, must be fully destroyed. In the final products, only $\mathrm{MnN}_{4} \mathrm{~S}_{2}, \mathrm{SbS}_{3}$, and $\mathrm{SbS}_{4}$ units are observed. In situ X-ray scattering experiments are under way for a better understanding of this complex reaction.

Thermal Investigations. The thermal stability of the title compounds were investigated using simultaneous differential thermoanalysis (DTA) and thermogravimetry (TG) measurements under a $\mathrm{N}_{2}$ atmosphere. Compound $\mathbf{1}$ decomposes in two steps with a total weight loss of $23.4 \%$ which is accompanied by two endothermic events with peak temperatures at $T_{\mathrm{p}}=277.4{ }^{\circ} \mathrm{C}$ and $295.0{ }^{\circ} \mathrm{C}$ (Figure 6). Unfortunately, the two thermal reactions are too close, preventing a more detailed study of the decomposition mechanism. In the

3730 Inorganic Chemistry, Vol. 45, No. 9, 2006 


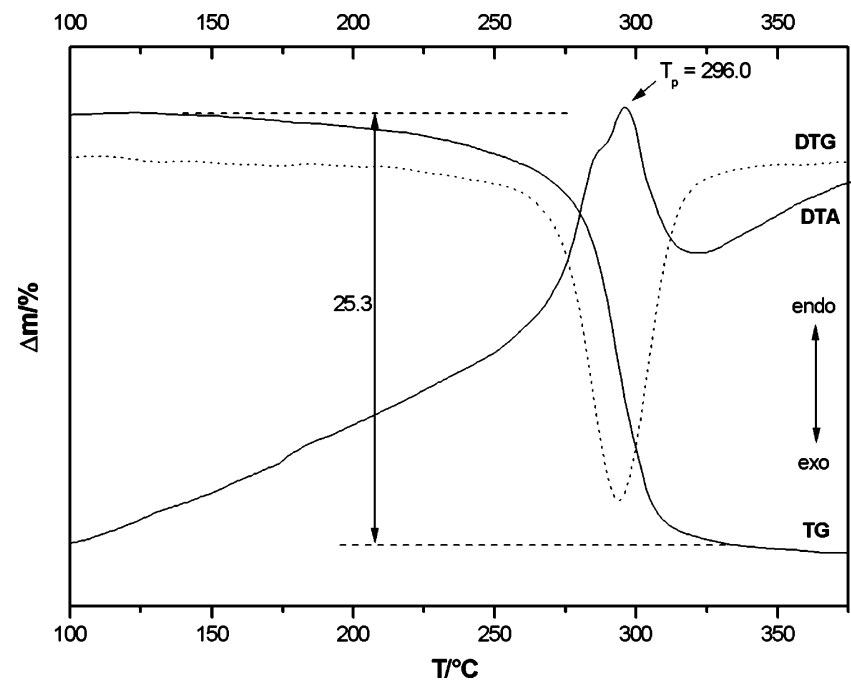

Figure 7. DTA, TG, and DTG curves for compound $2\left(T_{\mathrm{p}}=\right.$ peak temperature).

X-ray powder pattern of the gray decomposition product elemental $\mathrm{Sb}, \mathrm{MnS}$, and $\mathrm{Sb}_{2} \mathrm{~S}_{3}$ could be identified.
The decomposition of compound $\mathbf{2}$ starts at approximately $150{ }^{\circ} \mathrm{C}$ in one step with a total weight loss of $25.3 \%$ which is accompanied by a broad endothermic event at $T_{\mathrm{p}}=296.0$ ${ }^{\circ} \mathrm{C}$. The endothermic signal shows a shoulder at the lower temperature side indicating that the material is decomposed in two very close steps which cannot be resolved (Figure 7). Again, the $\mathrm{X}$-ray powder pattern shows only reflections from $\mathrm{MnS}$ and $\mathrm{Sb}_{2} \mathrm{~S}_{3}$. In both cases, the weight loss can be attributed to the removal of the tren ligand. The slightly different values for $\Delta m_{\exp }$ can be attributed to a contamination of the decomposition products with small amounts of $\mathrm{C}$ and $\mathrm{N}$.

Acknowledgment. We gratefully acknowledge financial support from the State of Schleswig-Holstein and the Deutsche Forschungsgemeinschaft (DFG). We also thank Inke Jess for the acquisition of the single crystal data and Uschi Cornelissen for the spectroscopic investigations.

IC0519739 